University of Windsor

Scholarship at UWindsor

\title{
Can managers use handheld technologies to support salespeople?
}

Francine K. Schlosser

Odette School of Business, University of Windsor

Follow this and additional works at: https://scholar.uwindsor.ca/odettepub

Part of the Business Commons

\section{Recommended Citation}

Schlosser, Francine K.. (2007). Can managers use handheld technologies to support salespeople?. Qualitative Market Research, 10 (2), 183-198.

https://scholar.uwindsor.ca/odettepub/117

This Article is brought to you for free and open access by the Odette School of Business at Scholarship at UWindsor. It has been accepted for inclusion in Odette School of Business Publications by an authorized administrator of Scholarship at UWindsor. For more information, please contact scholarship@uwindsor.ca. 
RUNNING HEAD: Mobile Technology and Supervisor Supportive Monitoring

\title{
Can Managers Use Handheld Technologies to Support Salespeople?
}

\author{
Francine K. Schlosser
}

University of Windsor, Canada

Correspondence to:

Francine K. Schlosser, Ph.D.

Assistant Professor, Management

Odette School of Business

University of Windsor

Windsor, ON

N9B 3P4

Email: fschloss@uwindsor.ca

Phone: (519) 253-3000 ext. 3107

Fax: (519) 973-7073

CITATION: Schlosser, Francine K., Can Sales Managers Use Handhelds to Monitor Sales

People and Support Good Relationships?, Qualitative Market Research: An International

Journal Special Issue on Ubiquitous Human Observation Methodologies(10(2)), 183-198, 2007, January. 


\begin{abstract}
Purpose:

This paper proposes that sales managers use mobile technologies in the working environment to communicate and supportively monitor sales person performance. Telecommuting, virtual teamwork and related work-family balance demands have challenged leaders to manage remote relationships. For example, perceptions of the leader-follower relationship might be affected by the ubiquitous nature of handheld portable wireless devices (handhelds) by changing the quality and quantity of communication. Handhelds allow managers to substitute electronic check-ups for traditional observational monitoring behaviors such as surveillance, management by walking around, and "bedchecks". Now sales managers can gather similar information by electronically assessing the availability of sales people to respond to queries posed via handhelds.
\end{abstract}

\title{
Methodology/Approach:
}

A model of supervisor monitoring using mobile technologies is conceptualized that specifies (1) the types of behaviours that promote high quality working relationships, (2) how mobile technologies increase the likelihood of work-to-nonwork role spill-over that may damage the relationship and (3) why perceptions of supervisor fairness are critical. The paper concludes by presenting strategies for testing hypotheses and for researching mobile technology use by sales managers using qualitative and quantitative methods.

\section{Originality/Value of the Paper:}

This paper aligns research in the areas of leadership, monitoring and ubiquitous or mobile technologies. Previous leadership researches have questioned whether or not the use of different electronic monitoring tools affects the leader's ability to influence others. However, few researchers have examined performance-based monitoring using mobile technologies, although mobile technologies make it easier for sales managers to monitor non-traditional work arrangements (i.e., off-site or contracted work). Furthermore, past research has been inconsistent in explaining how employees view information-gathering or monitoring by their managers.

\section{Paper Categorization: $\quad$ Conceptual Paper}

Key Words: LMX, Interactional Justice, Work-to-Nonwork Spillover, Mobile Technology, Monitoring, Sales 


\section{Can Managers Use Handheld Technologies to Support Salespeople?}

\subsection{Introduction}

The availability of mobile technologies is changing the nature of the supervisor-employee relationship. For example, sales managers can now communicate via wireless handheld devices ("handhelds"), which are portable and often include "always on" data and voice messaging capabilities. These attributes indicate movement toward a ubiquitous quality (Abowd \& Mynatt, 2000; Franklin, 2000; Weiser, 1991) and facilitate even greater worker mobility. Sales managers may use this mobile technology to interact with and monitor their offsite salespeople when opendoor leadership strategies and managing by walking around are no longer possible. Furthermore, handhelds may affect the frequency and the character of employee observation by sales managers.

Subsequently, a change in the interaction between a sales manager and a salesperson may arise from the sales manager's use of ubiquitous technologies (such as handhelds), and may influence employee perceptions of the supervisor-employee relationship. Thus, this paper examines how salesperson perceptions of supervisor monitoring using mobile technology may influence their perceptions of the supervisor-employee relationship. This is important to study in order to test the robustness of past leadership theories in today's context (Avolio, Kahai, and Dodge, 2001) and to add to the theoretical body of knowledge surrounding the supervisoremployee relationship, or the leader-member exchange. In this article, a model and hypotheses are developed that connects supervisor monitoring using mobile technology to employee perceptions of interactional justice and the supervisor-employee relationship. 
Traditional interaction between managers and employees has been studied extensively under a framework called the Leader-Member Exchange (LMX: Schriesheim Castro, \& Cogliser, 1999). LMX has its roots in social exchange and leadership theories, and is defined as the "quality of exchange" between a leader and follower (Schriesheim, Castro, and Cogliser, 1999). Although there has been little research considering the effect of supervisor technology-practice on the leader follower relationship, the widespread acceptance of the LMX framework, its concentration on supervisor-employee relationships, and the interactive nature of handheld technology suggests that LMX provides an appropriate theoretical base.

This paper aligns research in the areas of leadership, monitoring and ubiquitous or mobile technologies. In the leadership literature, Kahai, Sosik, and Avolio (1997) have questioned whether or not the use of different electronic monitoring tools affects the leader's ability to influence others. Other researchers have echoed this call to study human interaction with different types of electronic monitoring technologies (Zweig and Webster, 2002). We respond to both demands by examining leadership within a monitoring technology context.

This article considers monitoring outside of the traditional performance monitoring focus and issues of fairness and work-family role spillover. Managerial monitoring has been defined as "the gathering of information about work activities and external conditions affecting the work, checking on the progress and quality of work, and evaluating the performance of individuals and effectiveness of the organisational unit" (Kim \& Yukl, 1998, p. 248). Thus, this definition includes aspects of gathering and giving information (feedback). Few researchers have examined performance-based monitoring using mobile technologies (Stanton \& Weiss, 2002) although mobile technologies make it easier for sales managers to monitor sales work arrangements (i.e., off-site or contracted work). Furthermore, past research has been inconsistent 
in explaining why employees view information-gathering or monitoring by their managers both negatively and positively.

Information management has continually emerged as an important issue in the global corporations of today, and underlies the concepts of gatekeepers, innovation, and learning organizations. Managers cannot make effective decisions nor establish motivating and satisfying reward structures without gathering information, understanding employees and their needs, and providing employees with relevant feedback. In spite of its importance, monitoring has largely been ignored by leadership theorists, as these theorists have frequently preferred to focus on honing the strategic decision-making skills of leaders (i.e. Vroom \& Yetton, 1973). Leadership researchers consider how leaders influence employees toward a desired goal, whereas monitoring presents a less attractive and potentially coercive picture of management.

Technological advances have enabled sales managers to change the ways in which they interact with their sales people. As a result of societal and demographic developments, this interaction has become less face-to-face and more mobile in nature. Telecommuting, virtual teamwork and related work-family balance demands have challenged leaders to manage remote relationships. For example, perceptions of the leader-follower relationship might be affected by the ubiquitous nature of handheld portable wireless devices (handhelds) by changing the quality and quantity of communication. When a person continuously carries an activated handheld, they may experience more frequent communication with co-workers and sales managers. These communication differences may influence the ways that both parties feel about each other by either enhancing the supervisor-employee relationship or creating an impression of unfair scrutiny. 
In the past, managers monitored mobile employees through assignment of duties where results are easily measured, such as in units of quality and timeliness instead of direct observation. Although managers now use email technology to monitor employees through employee self-report, we suggest that the introduction of handheld technology facilitates a more continuous monitoring and interaction. Handhelds allow managers to substitute electronic check-ups for traditional observational monitoring behaviours such as surveillance (Kruglanski, 1970), management by walking around (Mintzberg, 1973), and "bedchecks" (Perlow, 1998, p. 342). Therefore, sales managers gather similar information by electronically assessing the availability of sales people to respond to queries posed via handhelds.

Researchers also studied the presence and characteristics of feedback in conjunction with monitoring. They suggested that feedback plays a role in the way that employees perceive and accept monitoring, and in final employee outcomes such as effectiveness and performance (e.g. Komaki, 1998). These are important to consider within the context of this article, because handhelds provide managers with the opportunity to give off-site employees more frequent and timely feedback than traditional face-to-face and written feedback. Sales managers can communicate while tasks are performed, rather than delaying feedback until sales people return to the office. Furthermore, with "always on" features, feedback timing can occur outside of "regular" work hours. This creates opportunities for sales managers who use handhelds to maintain close communication with sales people and to model expectations, and to dispel some of the ambiguities associated with performing off-site work.

Alternatively, these technical capabilities facilitate supervisory intrusion and control over employees, and indicate that sales managers work with their sales people to set guidelines for availability and interruption. The object of the monitoring may become less clear through 
handheld technology-practices, creating employee confusion as to whether the sales manager is "checking up" on them personally or on the status of the task for which they are responsible. These behaviours and motives may be viewed as destructive instead of supporting employee efforts.

\subsection{Supervisor-Employee Relationship}

This paper views the supervisor-employee relationship through the lens of leader-member exchange theory. LMX is "distinguished from other leadership theories by its focus on the dyadic relationship between a leader and a member" (Gerstner \& Day, 1997, p. 827). LMX is based upon the premise that "leaders differentiate in their treatment of employees" and create a situation where certain employees will enjoy a preferred or higher quality relationship (Dansereau, Graen, \& Haga, 1975; Liden, Wayne, \& Sparrowe, 2000, p. 409). In their metaanalysis, Schriesheim, Castro, and Cogliser (1999) noted that LMX has usually been defined as the "quality of exchange" between a leader and follower. A higher quality of exchange results when sales managers and sales people exchange greater physical resources, information and enjoyable tasks (Liden \& Maslyn, 1998). Dienesch and Liden (1986) pointed out that a high quality relationship is developed through a series of exchanges, prompted by one party's behaviour and the other party's reception of the behaviour. In addition, Liden and Maslyn (1998) identified this high-quality relationship as consisting of four highly-correlated dimensions: affect, loyalty, contribution, and professional respect. As there was often difficulty distinguishing between loyalty and trust, the researchers included a trust component within the dimension of loyalty. 
Some researchers have questioned whether LMX continues to be an appropriate theoretical platform to study modern work-related interactions (Rousseau, 1998). However, research on remote relationships discovered that it is still possible to cultivate a high LMX in spite of the geographical distance between a supervisor and employee (Howell \& Hall-Merenda, 1999). Furthermore, it is also relevant to consider trust-based theories such as LMX when considering off-site work because trust promotes positive employee outcomes for remote workers (Staples, 2001). Trust plays a valuable role in the way that remote communication is conducted and interpreted and in allowing employees to feel connected. Therefore, although other leadership theories may be applicable, this article seeks to discover what type of factors accompany a high quality supervisor-employee relationship when using an interactive mobile technology.

Employee perceptions of heightened reciprocity (Sparrowe \& Liden, 1997; Deluga, 1998), leader effort (Maslyn \& Uhl-Bien, 2001), procedural justice and leader trustworthiness (Flaherty \& Pappas, 2000), and leader power (Cogliser \& Schriesheim, 2000) predict a highquality LMX relationship. Previous research on effort suggests that the employee is less likely to take the initiative to correct a relationship (Maslyn \& Uhl-Bien, 2001). Thus, the relationship may be abandoned unless the leader believes the employee appreciates and returns the leader's efforts. This raises the importance of supervisory actions in forming and sustaining high LMX.

Few studies have examined leaders' behaviours as antecedents to LMX. This is surprising as past researchers have concluded that one reason for studying LMX is to develop "a prescriptive approach to LMX building" (Graen \& Uhl-Bien, 1998). This prescriptive approach trains leaders to practice effective relationship-building with their followers and underlines a 
need to study the influence of supervisor behaviours on the quality of the relationship between sales managers and sales people.

Earlier studies by Graen, Novak, and Sommerkamp (1982) and Scandura and Graen (1984) tested a supervisory training model wherein sales managers were trained to practice four types of high quality LMX behaviours. Interestingly, each high-quality behaviour involved leader monitoring of employees. Leaders typically monitor employees by gathering information (Kim \& Yukl, 1998) and measuring against expectations (Komaki, 1998). Graen and colleagues trained leaders to gather information by asking about employee expectations and by practicing active listening. Then, as leaders were taught to communicate their expectations, they initiated and completed the feedback loop, by providing feedback and setting standards for monitoring. Such LMX-oriented behaviours appear to support monitoring as an effective manager's duty.

In contrast to monitoring behaviours that make leaders more effective, Howell and HallMerenda (1999) found behaviours that are negatively related to LMX. Using items from Bass and Avolio's (1995) Multifactor Leadership Questionnaire, they measured transactional leadership behaviours at a distance. However, an emphasis on leader action only when things were going wrong, may have focused the participants' thoughts on negatively perceived monitoring actions of ineffective managers. Thus, the Scandura and Graen (1984) and the Howell and Hall-Merenda (1999) studies both imply that monitoring behaviours may influence the development of supervisor-employee relationships and specifically that employees may perceive leader monitoring actions either positively or negatively.

Such results mirror conflicting results found in other streams of monitoring research. In the traditional management literature, the focus is on face-to-face interaction and concludes that monitoring is the duty of any effective manager (e.g., Kim \& Yukl, 1998; Komaki, 1998; Larson 
\& Callahan, 1990; Mintzberg, 1978; Quinn, Faerman, Thompson, \& McGrath, 1996). However, in the electronic performance-monitoring literature, the focus is on remote or system-based interaction and the results are more mixed depending on the monitoring context (Aiello, 1993; Aiello \& Svec, 1993; Stanton, 2000).

\subsection{Development of a Research Model and Hypotheses}

Our review of the literature shapes the development of a research model and hypotheses (Figure 1). In the model, we propose that how sales managers use mobile technologies to monitor sales people will be related to sales people's perceptions of LMX and strengthened by perceptions of interactional justice and low work to non-work spillover.

take in Figure 1

\subsection{Supportive Supervisory Monitoring Using Mobile Technologies}

Employees "develop general views concerning the degree to which supervisors value their contributions and care about their wellbeing" (Eisenberger, Stinglhamber, Vandenberghe, Sucharski, and Rhoades; 2002). These views are important because supervisors influence the direction, support, and recognition employees receive from their organization (Eisenberger et al., 2002). Hackman and Walton (1986, p. 85) have concluded that leaders must exhibit supporting and helping behaviours in order to create an effective team. As "help providers", leaders minimize process losses and create gains. Conversely, unsupportive behaviours are characterized by controlling and selfish motives and may create annoying interruptions and process losses. These differing perceptions of managerial monitoring behaviours are also present 
in the LMX literature. For example, Scandura and Graen (1984) have trained leaders in supportive behaviours, and Howell and Hall-Merenda (1999) have studied more unsupportive behaviours.

Managerial monitoring researchers have produced mixed findings on the effectiveness of various monitoring methods. For example, Mintzberg (1973) observed and interviewed managers regarding critical incidents on the job. He encouraged managers to ignore the formal information hierarchy, and suggested that they check operational reports, solicit input from employees, and actively involve themselves in day-to-day events. In contrast, a later study by Perlow (1998) concluded that similar leader behaviours had created a counter-quality company culture based on impression management. This may indicate differences in perspective between managers and employees, because Mintzberg dealt with managers, but Perlow interviewed employees. In support of this explanation, Oz, Glass, and Behling (1999) surveyed 823 employees, and found that supervisors were more likely to favour monitoring strategies, whereas employees were more likely to dislike them. Managers considered monitoring to be part of their jobs, but employees believed that it just made the relationship more difficult. Additionally, it is possible that employees may perceive leader behaviours differently, depending on the motives attributed to the behaviours of their managers.

Researchers in both the LMX and management literatures have described monitoringtype behaviours as leading to higher quality relationships (Komaki 1998; Scandura \& Graen, 1984). We suggest that in the process of monitoring, as information is gathered and feedback provided, this information exchange leads to a higher quality relationship. Consequently, both parties develop a better understanding of each other, and build trust through information sharing. 
Also, results of a study conducted by Howell and Hall-Merenda (1999) imply that a lack of proactive and supportive monitoring behaviours are detrimental to LMX development. They found that management by exception, or monitoring that focused only on negative events with little feedback provided, created a lower quality relationship. Therefore, employees' perceptions of the LMX relationship may depend on the employees' perception of how constructively handhelds are used. Thus, we propose that:

Hypothesis 1: The more sales managers are perceived to engage in supportive monitoring using mobile technologies, the higher the perceived quality of the supervisor-employee relationship.

\subsection{Supervisory Monitoring and Interactional Justice}

Interactional justice is composed of two dimensions, interpersonal justice and informational justice (Greenberg, 1993). We suggest that supportive monitoring technologypractice may be related to each dimension. Dignity, respect and politeness are considered to be dimensions of interpersonal justice (e.g., Colquitt, 2001) and have also been related to monitoring system acceptance. To elaborate, past researchers have suggested that managers may feel that monitoring is a right (Vaught, Taylor, \& Vaught, 2001), whereas employees may take a different stand with concerns that their dignity and privacy may be violated (Baarda, 1994; Oz et al., 1999; Rosenberg, 1999). Consequently, it is probable that there is a link between supportive monitoring technology-practice and interpersonal justice.

Informational justice focuses on whether or not employees believe supervisors have communicated information in an honest and helpful way. For example, Scandura (1999) theorized that the first test of a leader (in developing high-quality LMX) is honesty in dealing 
with members. Justice researchers have suggested that if supervisors communicate with respect and honesty, employees perceive higher interactional justice (e.g., Greenberg, 1993). Similarly, Shapiro, Buttner, and Barry's (1994) informational justice scale measures whether supervisors communicate candidly, while tailoring communications to individual employee needs, and reflects the product of a successful supportive approach to feedback. Thus, if supervisors monitor by gathering and responding with useful and helpful information to employees, then employees may believe that they are being treated fairly.

Interactional justice, or the fairness of interpersonal treatment, leads to supervisorreferenced outcomes such as employees' positive evaluations of supervisory authority and organisational citizenship behaviours (OCBs) directed at supervisors (Bies \& Moag, 1986). The supervisor is perceived to be responsible for the fairness of interaction.

Previous researchers differ in their conclusions regarding the effects of supervisor monitoring behaviours on employees. For example, Ambrose and Alder (2000) have theorized that a high degree of monitoring may erode trust and fairness. This perception may arise through a comparison with how much other employees are monitored or in the belief that the supervisor does not trust the employee to fulfill job duties correctly. Consequently, they suggested a curvilinear relationship depicting some monitoring as fairer than no monitoring, but high levels of monitoring as unfair. In contrast, when Niehoff and Moorman (1993) measured supportive monitoring behaviours such as observations, manager-initiated discussions, and formal meetings in a national movie theatre management company, their results indicated that more frequent monitoring positively influenced fairness. These results may imply that the amount of monitoring is secondary to some other quality inherent in the way that the monitoring is 
performed. We suggest that whether or not the monitoring behaviours are seen as supportive or destructive may be influenced by employees' perceptions of interactional justice.

The supervisor who monitors by gathering information is in a good position to understand employee needs and views. Supportive supervisory behaviours stem from recognition of and response to these needs and views. When developing his framework of managerial roles, Mintzberg (1973) noted that the CEO "emerges as the nerve center of internal and external information of the organization" (p. 92), and that "he uses his information ... to determine organisational values" (p. 97). Consequently, Niehoff and Moorman (1993) suggested that monitoring by gathering information is positively related to perceptions of interactional justice because employees perceive that their supervisors have more accurate information. Such accuracy of information ensures that supervisors are more able to evaluate, support and reward employees according to their true performance.

In the electronic performance monitoring literature, researchers have suggested that employees place importance on the ways that managers use and respond to the information provided by monitoring (Ambrose \& Alder, 2000). This research draws on Baron's (1993) proposed relationship between constructive criticism and employees' perceptions of interpersonal justice. Specifically, Baron (1993, p. 165) proposed that the "success of criticism in producing its desired goal of change is strongly mediated by recipients' perceptions of the extent to which it's fair". For instance, Alder (2000) concluded that feedback delivered constructively is viewed as more fair than feedback delivered destructively, because employees perceive constructive feedback to be rooted in the supervisor's desire to help them improve. Other researchers have suggested that supervisory consideration behaviours such as active 
listening and constructive suggestions predict employee perceptions of interactional and procedural justice (Phillips, Douthitt, \& Hyland, 2001).

When employees believe that supervisors treat them with honesty and respect, and give adequate explanations for their inquiries, the resulting perception of interactional justice leads to a high-quality LMX (Masterson et al., 2000). The leader is perceived to be a "straight-shooter" who will treat employees fairly. Such a connection between interactional justice and employee perceptions of leaders has also been noted in Colquitt, Conlon, Wesson, Porter, and Ng's (2001) meta-analysis. In this, the researchers demonstrated that informational justice is the strongest predictor of agent-referenced and system-referenced evaluations of authority ${ }^{1}$. Phillips et al. (2001) demonstrated a connection between interactional justice (collapsed with procedural justice) and leader-referenced evaluations, when they found that employees' perceptions of justice explained 56\% of the variance in satisfaction with their leaders. Kurland and Egan (1999) noted that these social aspects of procedural justice influenced supervisor-employee relationships. They realized that the use of email strengthened remote relationships by allowing employees to voice concerns and to provide input. Thus,

Hypothesis $2:$ Perceptions of interactional justice will strengthen the relationship between employee perceptions of supportive supervisory monitoring using mobile technologies and a high quality supervisor-employee relationship.

\subsection{Supervisory Monitoring and Perceptions of Work-to-Nonwork Spillover}

Previous researchers have discussed the way that structural, instrumental, emotional and social aspects of work spill over from the work to the non-work domains (e.g. Kanter, 1977). Mobile

\footnotetext{
${ }^{1}$ Agent-referenced evaluation of authority describes an immediate authority figure such as a supervisor, whereas system-referenced evaluation describes the organization or system in general.
} 
technologies make it easier to integrate work and non-work domains, because the devices increase employee accessibility and connectivity over spatial boundaries such as time and location.

Past studies have reflected these changes in boundaries between employees' personal selves and the selves that they reveal at work. For example, in a qualitative study, Schlosser (2002) found that handhelds stimulated new ways for participants to manage work relationships, and integrate work and other responsibilities. As employees found themselves adapting to the technology, the technology was also adapted to their lives, changing work and personal boundaries. Perlow (1998) discussed attempts by management to manipulate the boundaries set by employees. In Perlow's study, managers who frequently monitored employees encouraged employees to work longer hours. Similarly, Zweig and Webster (2002) conducted a crosssectional study of factors influencing video monitoring acceptance. Although the participants acknowledged differences in system characteristics, the protection of an individual's personal boundaries appeared to influence their attitudes toward the monitoring system. Furthermore, the handheld users interviewed by Schlosser (2002), considered it necessary to protect their time for spiritual and personal revitalization from unwanted intrusion via handhelds.

Additionally, a recent study (Higgins \& Duxbury, 2002) indicated that while formal flextime and tele-work arrangements are still relatively rare, many workers engage in "guerrilla" telework, that is, informal work done at home. Consequently, they experience increasing unpaid overtime, and find it more difficult to meet organisational expectations during regular work hours. Other research has linked work overload and organisational expectations with negative work-to-nonwork spillover (Major, Klein, \& Ehrhart, 2002; Wallace, 1999) and through this spillover to job dissatisfaction (Kossek \& Ozeki, 1998, as cited in Martins, Eddleston, \& Veiga, 
2002) and psychological distress (Major et al., 2002). Because supervisors act as agents of the organization, employees may view organisational expectations through the monitoring practices and expectations of their supervisors.

At the organisational level, Kirchmeyer (1995) conducted a field study examining the effectiveness of three management responses to work-to-nonwork boundaries: 1) complete separation, where employees are expected to leave non-work issues at the door, 2) integration policies such as gyms, on-site daycare, and employee assistance plans, and 3) respect for nonwork employee concerns. She concluded that while integration policies did not appear to influence employee attitudes, the existence of policies respecting employee work-to-nonwork role boundaries was positively related to organisational commitment. This finding indicates that supervisor consideration of the spillover between work and non-work roles would also be important in a mobile technology context, as such ubiquitous technologies facilitate unprecedented supervisory manipulation of the boundaries dividing these roles. Because supportive monitoring behaviours concern the extent to which supervisors value employees' well being, supportive behaviours respect that employees will be less stressed when they are allowed to balance both work and family lives, and to control or limit work-to-nonwork spillover. Consequently, Hypothesis 3: Perceptions of work-to-nonwork spillover will weaken the relationship between employee perceptions of supportive supervisory monitoring and a high quality supervisor-employee relationship. 


\subsection{Implications for Research and Methodological Considerations}

The purpose of this article is to stimulate research and thinking about the effects of mobile technology-practice in the workplace and on supervisor-employee relationships. Finally, this paper suggests several implications for future research.

\subsection{Definition of Technology}

In order to test these hypotheses, researchers must clearly define what aspect of ubiquitous technology they will be studying. For example, technology can be discussed in a generic social technological context, as it "includes generic tasks and techniques and knowledge utilized when humans engage in productive activities, makes it more meaningful across time and organizations". However, in defining technology so ambiguously, we lose sight of the richness of interaction between different aspects of the technology like the task and the tools, and between people utilizing specific technological artifacts, such as handhelds (Orlikowski, 1999).

Therefore, we suggest that there is merit in both a long-term generic approach to technology as well as considering how managers can develop good communication and monitoring practices while using mobile technologies.

Furthermore, researchers must decide whether technology will be defined in terms of the device type (e.g. handheld/cellphone/pager/beeper, handheld personal computer), characteristics of the task (e.g. structured, unstructured, complex, simple, on or offsite), or the device's mobile functional capability (i.e. voice, text/text attachment/email, availability/interruption alert, visual/teleconference). Building upon this definition, it will be necessary to observe supportive supervisory monitoring uses of mobile technologies by gaining access to conversational streams involved in technological chats and emails. Future researchers should also consider a research design that involves a comparison of different types of mobile technologies. Analysis of the 
differences in the effect size would augment our understanding of the importance of the relationship between ubiquitous mobile technology use and leader-member exchange.

\subsection{Enduring Relevance of Ubiquitous Technologies}

There is also a fundamental question surrounding the ubiquitous quality of these technologies. To clarify, the use of mobile technologies may become so natural and unobtrusive, that the nature and structure of interpersonal relationships will not truly change. However, we suggest that member expectations and relationship routines will experience enduring changes, as people develop new structural and social meanings and gain a shared interpretation of the technology. Researchers who have studied human-computer interaction, such as Desanctis and Poole (1994), Orlikowski (1999), Palen, Saltzman, and Youngs (2000), Saga and Zmud (1994), and Schlosser (2002), have discussed how people adapt their routines to technology, as well as adapting the technology to their routines.

Proponents of socio-technical research (e.g. Bijker, 1995; Willoughby, 1990) have discussed the way that this social construction of meaning may change over time or from interest group to group and thus determine which types of technology might survive. Similarly, Orlikowski's (1999) structurational model of technology outlines two principles that encourage iterative and recursive changes to both the technology and the human processes.

The first principle, the duality of technology, considers technology to be "physically constructed by actors working in a given social context and technology is socially constructed by actors through the different meanings they attach to it and the various features they emphasize and use" (Orlikowski, 1999, p. 406). Handhelds have been physically developed to enhance communications, and information availability (meeting goals of efficiency and effectiveness) but 
have also assumed different social meanings to different people in different social contexts, such as the meanings centered around aspects of self-identity (Schlosser, 2002).

The second principle, the interpretive flexibility of technology, considers technologies to be differentiated in terms of how well they allow users to continually adapt the technology to their needs (Orlikowski, 1999). Handheld technology is very flexible - more flexible than many automated systems. Each individual can customize their use of the devices, in terms of functions like email, voice, data, pager, planner, or in terms of social/personal norms of use like presence and availability, and language. Thus, these forces of technological evolution necessitate further study of ubiquitous technology-practice and underlying interpersonal relationships.

\subsection{Contextual influences}

LMX's premise of differentiated relationships between leader and follower (Schriesheim et al., 1999) highlights contextual issues with any theory that attempts to prescribe certain behaviours as being conducive to a high quality relationship. Researchers should explore variables previously found to have a significant effect on relationship quality. For example researchers have differed in their conclusions relating to a gender effect on LMX perceptions; some not finding a relationship (Bauer \& Green, 1996; Liden, Wayne, \& Stilwell, 1993), and others reporting a significant effect (Murphy \& Ensher, 1999; Varma \& Stroh, 2001). Additionally, data on reporting relationship tenure should be collected because LMX develops over time (Scandura and Graen, 1984). Supervisory status is important because attitudinal differences exist between managers and employees (e.g., Oz et al., 1999; Vaught et al., 2001).

\subsection{Relationship measurement}

In addition to definition and context issues, researchers must consider the debate surrounding the measurement of the leader-follower relationship. While the LMX measure has 
been viewed as multi-dimensional by Liden and Maslyn (1998), other researchers have suggested that the measure is uni-dimensional due to high inter-correlations between LMX dimensions of respect, trust and obligation (Graen \& Uhl-Bien, 1998), and notably from the employee's point-of-view since all items in the scale are leader referent (Gerstner \& Day, 1997). These issues indicate that a qualitative method may be more appropriate for assessing relationship quality. A structured interview covering the behaviours identified by previous LMX researchers, yet phrased in an open-ended style, will allow the researcher to uncover employee perceptions of high quality relationship behaviours (possibly not contemplated by older measures) arising from changes in technology.

\subsection{Conclusion}

This paper presents managers with a framework that can be used to model and test effective use of mobile technologies. Mobile technology use, supervisory monitoring, and relationship development co-exist in the current workplace. Such research heightens awareness of how work-to-nonwork spillover may influence important outcomes of mobile technology usage. Perceptions of quality supervisor-employee relationships are important to retaining and motivating employees. As the workforce ages and skilled workers become more scarce, we expect this theoretical examination and ensuing future research to be interesting and important to the $21^{\text {st }}$ century manager. 


\section{References}

Abowd, G., Mynatt, E. (2000), "Charting past, present and future research in ubiquitous Computing”, ACM Trans Computer-Human Interaction, Vol 7 No 1, pp 29-58.

Aiello, J. R. (1993), “Computer-based work monitoring: Electronic surveillance and its effects”, Journal of Applied Social Psychology, No 23, pp 499-507.

Aiello, J. R., Svec C. M. (1993), "Computer monitoring of work performance: Extending the social facilitation framework to electronic presence", Journal of Applied Social Psychology, Vol 23 , pp $537-548$.

Alder, G. S. (2000), "Computer performance monitoring and fairness: The role of feedback", Presented to the Academy of Management Annual Meeting (AOM), Western Illinois University, Macomb, Illinois.

Ambrose, M. L., Alder, G. S. (2000), "Designing, Implementing, and Utilizing Computerized Performance Monitoring: Enhancing Organizational Justice", in Ferris, G.R. (Ed.), Research in Personnel and Human Resources Management (18, pp. 187-219). JAI Press, Greenwich, CT.

Avolio, B., Kahai, S., Dodge, G. (2001), "E-leading in Organizations and its Implications for Theory, Research and Practice”, Leadership Quarterly, Vol 11 No 4, pp 615-668.

Baarda, C. (1994), “Computerized performance monitoring: Implications for employers, employees, and human resource management", Kingston: Industrial Relations Centre Press, Queen's University.

Baron, R. M. (1993), "Criticism (Informal negative feedback) as a source of perceived unfairness in organizationas: Effects, mechanisms, and countermeasures", in Cropanzano, R. (Ed.), Justice in the Workplace: Approaching Fairness in Human Resource Management (pp. 155-170). Erlbaum, Hillsdale, NJ.

Bass, B.M., Avolio, B. J. (1995), Manual for the multifactor leadership questionnaire: Rater form (5X Short). Mind Garden, Palo Alto, CA.

Bauer, T. N., Green, S. G. (1996), "Development of leader-member exchange: A longitudinal test", Academy of Management Journal, Vol 39, pp 1538-1567.

Bies, R. J., and Moag, J. F. (1986), "Interactional justice: Communication criteria of fairness", In Lewicki, R. J., Sheppard, B.H. \& Bazerman, M. H. (Eds.), Research on Negotiations in Organizations (Vol. 1, pp. 43-55). JAI Press, Greenwich, CT.

Bijker, W. E. (1995), Of Bicycles, Bakelites, and Bulbs: Toward a Theory of Socio-technical Change. The MIT Press, Cambridge, MA. 
Cogliser, C. C., and Schriesheim, C. A. (2000), "Exploring work unit context and leader-member exchange: A multilevel perspective", Journal of Organizational Behavior, Vol 21, pp 487-511.

Colquitt, J. A. (2001), "On the dimensionality of organisational justice: A construct validation of a measure", Journal of Applied Psychology, Vol 86 No 3, pp 386-400.

Colquitt, J. A., Conlon, D. E., Wesson, M. J., Porter, C. O., Ng, K. Y. (2001), "Justice at the millennium: A meta-analytic review of 25 years of organisational justice research", Journal of Applied Psychology, Vol 86 No 3, pp. 425-445.

Dansereau, F., Graen, G., \& Haga W. J. (1975), “A vertical dyad linkage approach to leadership within formal organizations : A longitudinal investigation of the role-making process", Organizational Behavior and Human Performance, Vol 13, pp. 46-78.

Deluga, R. J. (1998), “Leader-member exchange quality and effectiveness ratings”, Group \& Organizational Management, Vol 23 No 2, pp. 189-216.

DeSanctis, G., Poole, M. (1994), "Capturing the complexity in advanced technology use: Adaptive structuration theory”, Organizational Science, Vol 5, pp.121-147.

Dienesch, R. M., Liden, R. C. (1986), "Leader-member exchange model of leadership: A critique and further development", Academy of Management Review, Vol 11 No 3, pp. 618629.

Eisenberger, R., Stinglhamber, F., Vandenberghe, C., Sucharski, I.L., Rhoades, L. (2002), "Perceived supervisor support: Contributions to perceived organisational support and employee retention”, Journal of Applied Psychology, Vol 87 No 3, pp. 565-573.

Flaherty, K. E., Pappas, J. M. (2000), "The role of trust in salesperson-sales manager Relationships”, Journal of Personal Selling \& Sales Management, Vol 20 No 4, pp. 271-278.

Ford, J. M., Greguras, G. J. (April 2002), "Leader-member exchange agreement: Examining the influence of supervisory-subordinate agreement on LMX relationships", Paper presented at the Seventeenth Annual Conference for the Society for Industrial and Organizational Psychology, Toronto, ON

Franklin, M. J. (2000), “Challenges in ubiquitous data management”, In Wilhelm, R. (Ed.): Informatics. 10 Years Back 10 Years Ahead (pp. 24-33). Springer-Verlag, Berlin.

Gerstner, C. R., Day, D. V. (1997), "Meta-analytic review of leader-member exchange theory: correlates and construct issues", Journal of Applied Psychology, Vol 82, pp. 827-844.

Graen, G., Novak, M., Sommerkamp, P. (1982), "The effects of leader-member exchange and job design on productivity and satisfaction: Testing a dual attachment model", Organizational Behavior and Human Performance, Vol 30, pp. 109-131. 
Graen, G. B., Uhl-Bien, M. (1998), "Relationship-based approach to leadership: Development of leader-member exchange (LMX) theory of leadership over 25 years: Applying a multi-level multi domain perspective", in Dansereau, F., Yammarino, F. J. (Eds). Leadership: the multiplelevel approaches: Part B. Contemporary and Alternative. (pp. 103-133). JAI Press, Stamford, CT.

Greenberg, J. (1993), "The social side of fairness: Interpersonal and informational classes of organisational justice", in Cropanzano, R. (Ed.), Justice in the Workplace: Approaching Fairness in Human Resource Management (pp. 79-106). Erlbaum, Hillsdale, NJ.

Hackman, J. R., Walton, R. E. (1986), "Leading groups in organizations", in P. S. Goodman and Associates (Eds.) Designing Effective Work Groups (pp. 72-119). Jossey-Bass Inc., San Francisco.

Higgins, C.,Duxbury, L. (March, 2002), “The 2001 National Work-Life Conflict Study: Report One, Health Canada", http://www.hc-sc.gc.ca/pphb-dgspsp/publicat/work-travail/index.html.

Howell, J. M., Hall-Merenda, K. E. (1999), "The ties that bind: The impact of leadermember exchange, transformational and transactional leadership, and distance on predicting follower performance", Journal of Applied Psychology, Vol 84 No 5, pp. 680-694.

Kahai, S. S., Sosik, J. J., \& Avolio, B. J. (1997), "Effects of leadership style and problem structure on work group process and outcomes in an electronic meeting system environment", Personnel Psychology, Vol 50, pp. 121-147.

Kanter, R. M. (1977), Work and family in the United States : A critical review and agenda for research and policy, Russell Sage Foundation, New York.

Kim, H., and Yukl, G. (1998), "Relationships of managerial effectiveness and advancement to self-reported and subordinate-reported leadership behaviours from the multiple linkage model", In Dansereau, F., Yammarino, F. J. (Eds.), Leadership : The Multiple-Level Approaches Classical and New Wave (pp. 243-264). JAI Press Inc., London, England.

Kirchmeyer, C. (1995), "Managing the work-non-work boundary: An assessment of organisational responses”, Human Relations, Vol 48, No 5, pp. 515-532.

Komaki, J. L. (1998), Leadership from an Operant Perspective, MPG Books Ltd., London.

Kruglanski, A. W. (1970), “Attributing trustworthiness in supervisor-worker relations", Journal of Experimental Social Psychology, Vol 6, pp. 214-232.

Kurland, N. B., Egan, T. D. (1999), “Telecommuting: Justice and control in the virtual organization”, Organization Science, Vol 10 No 4, pp. 500-513.

Larson, J. R., Callahan, C. (1990), "Performance monitoring: How it affects work productivity”, Journal of Applied Psychology, Vol 75, No 5, pp. 530-538. 
Liden, R.C., Maslyn, J.M. (1998), "Multi-dimensionality of leader-member exchange: An empirical assessment through scale development", Journal of Management, Vol 24 No 1, pp. 4372.

Liden, R. C., Wayne, S. J., Sparrowe, R. T. (2000), "An examination of the mediating role of psychological empowerment on the relations between the job, interpersonal relationships, and work outcomes", Journal of Applied Psychology, Vol 85, No 3, pp. 407-416.

Liden, R. C., Wayne, S. J., Stilwell, D. (1993), “A longitudinal study on the early development of leader-member exchanges”, Journal of Applied Psychology, Vol 78, pp. 662-674.

Major, V. S., Klein, K. J., Ehrhart, M. G. (2002), "Work time, work interference with family, and psychological distress”, Journal of Applied Psychology, Vol 87 No 3, pp. 427-436.

Martins, L. L., Eddleston, K. A., Veiga, J. F. (2002), "Moderators of the relationship between work-family conflict and career satisfaction", Academy of Management Journal, Vol 45 No 2, pp. 399-409.

Maslyn, J. M., Uhl-Bien, M. (2001), "Leader-member exchange and its dimensions: Effects of self-effort and other's effort on relationship quality”, Journal of Applied Psychology, Special Issue, Vol 86 No 4, pp. 697-708.

Masterson, S. S., Lewis, K., Goldman, B. M., Taylor, M. S. (2000), "Integrating justice and social exchange: The differing effects of fair procedures and treatment on work relationships", Academy of Management Journal, Vol 43 No 4, pp. 738-748.

Mintzberg, H. (1973), The Nature of Managerial Work. Harper \& Row, Publishers Inc., New York.

Murphy, S. E, Ensher, E. A. (1999), "The effects of leader and subordinate characteristics in the development of leader-member exchange quality”, Journal of Applied Social Psychology, Vol 29 No 7, pp. 1371-1394.

Niehoff, B. P., Moorman, R. H. (1993), "Justice as a mediator of the relationship between methods of monitoring and organisational citizenship behaviour", Academy of Management Journal, Vol 36, pp. 527-556.

Orlikowski, W. J. (1999), "The duality of technology - Rethinking the concept of technology in organizations", Organization Science, Vol 3 No 2, pp. 398-427.

Oz, E., Glass, R., Behling, R. (1999), "Electronic workplace monitoring: What employees think”, Omega, Vol 27 No 2, pp. 167-177. 
Palen, L., Salzman, M., Youngs, E., 2000. "Going wireless: Behaviour and practice of new mobile phone users", ACM Conference on Computer Supported Cooperative Work. [December 2-6, 2000: 201-210], Phil., PA.

Perlow, L. A. (1998), "Boundary control: The social ordering of work and family time in a hightech corporation”, Administrative Science Quarterly, Vol 43, pp. 328-357.

Phillips, J. M., Douthitt, E. A., Hyland, M. M. (2001), “The role of justice in team member satisfaction with the leader and attachment to the team", Journal of Applied Psychology, Vol 86 No 2, pp. 316-325.

Quinn, R. E., Faerman, S. R., Thompson, M. P., McGrath, M. R. (1996), Becoming a Master Manager: A Competency Framework. John Wiley \& Sons, New York.

Rosenberg, R. S. (1999), “The workplace on the verge of the $21^{\text {st }}$ century”, Journal of Business Ethics, Vol 22 No 1, pp. 3-14.

Rousseau, D. M. (1998), "LMX meets the psychological contract: looking inside the black box of leader-member exchange", in Dansereau, F., Yammarino, F.J. (Eds.), Leadership: the multiple-level approaches: Part B. Contemporary and alternative. (pp. 149-154). JAI Press, Stamford, CT.

Saga V.L., Zmud, R. W. (1994), "The nature and determinants of IT acceptance, routinization, and infusion", in Levine, L. (ed.), Diffusion, Transfer and Implementation of Information Technology, Elsevier Science B. V., North-Holland.

Scandura, T. (1999), "Rethinking leader-member exchange: An organisational justice perspective", Leadership Quarterly, Vol 10, pp. 25-40.

Scandura, T., Graen, G. B. (1984), "Moderating effects of initial leader-member exchange status on the effects of a leadership intervention", Journal of Applied Psychology, Vol 69, pp. 428436.

Schlosser, F. K. (2002), "So, how do people really use their handheld devices? An interactive study of wireless technology use", Journal of Organizational Behavior, Vol 23, pp. 401-423.

Schriesheim, C. A., Castro, S. L., Cogliser, C. C. (1999), "Leader-member exchange (LMX) research: a comprehensive review of theory, measurement and data-analytic practices", Leadership Quarterly, Vol 10, pp. 63-113.

Schriesheim, C. A., Castro, S. L., Zhou, X., Yammarino, F. J. (2001), “The folly of theorizing "A" but testing "B" A selective level-of-analysis review of the field and a detailed leadermember exchange illustration", Leadership Quarterly, Vol 12, pp. 515-551. 
Shapiro, D. L., Buttner, E. H., \& Barry, B. (1994), "Explanations: What factors enhance their perceived adequacy", Organizational Behavior and Human Decision-Making Processes, Vol 58, pp. 346-368.

Sparrowe, R. T. and Liden, R. C. (1997), "Process and structure in leader-member exchange", Academy of Management Review, Vol 22 No 2, pp. 522-552.

Stanton, J. M. and Weiss, E. M. (2002), "Electronic monitoring in their own words: an exploratory study of employees' experiences with new types of surveillance", Computers in Human Behavior, Vol 16, pp. 423-440.

Staples, D. S. (2001), "A study of remote workers and their differences from non-remote workers", Journal of End Use Computing, Vol 13, pp. 3-14.

Varma, A. Stroh, L. K. (2001), "The impact of same-sex LMX dyads on performance evaluations", Human Resources Management, Vol 40 No 4, pp. 309-320.

Vaught, B. C., Taylor, R. E., Vaught, S. F. (2001), "The attitudes of managers regarding the electronic monitoring of employee behaviour: Procedural and ethical considerations", American Business Review, pp. 107-114.

Vroom, V. H., Yetton, P. W. (1973), Leadership and decision-making. University of Pittsburg Press, Pittsburg.

Wayne, S. J., Shore, L. M., Liden, R. C. (1997), "Perceived organisational support and leadermember exchange: A social perspective", Academy of Management Journal, Vol 40 No 1, pp. $82-11$.

Weiser, M. (1991), “The computer for the $21^{\text {st }}$ century”, Scientific American, September, pp. 96104.

Willoughby, K. W. (1990), Technology Choice: A Critique of the Appropriate Technology Movement. Westview Press, Boulder.

Zweig, D., Webster, J. (2002), "Where is the line between benign and invasive? An examination of psychological barriers to the acceptance of awareness monitoring systems", Journal of Organizational Behavior, Vol 23 No 5, pp. 605-633. 
Figure 1: $\quad$ Model of Supportive Supervisory Monitoring

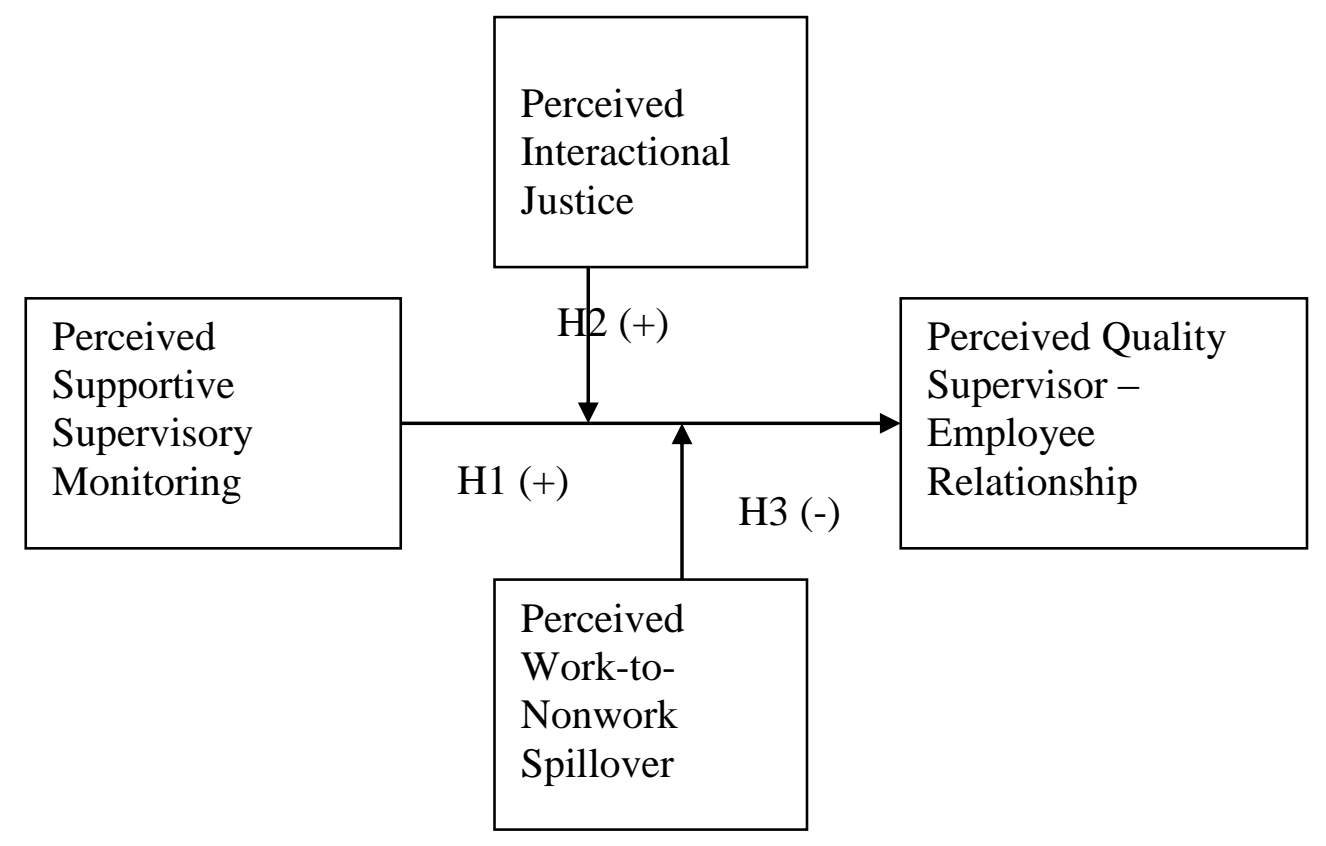

